\title{
State and Private Archives: Construction of the System of Relations and Opportunities of Cooperation
}

\author{
ANDREI RYBAKOU, PH.D. \\ Director Belarusian Research Institute for Documentation and Archival Science (BelNIIDAD), + 375172867693 , \\ Minsk, Belarus \\ e-mail: rybakou@belniidad.by
}

State and Private Archives: Construction of the System of Relations and Opportunities of Cooperation

$$
\text { ABSTRACT }
$$

The article is devoted to the search for optimal solutions for building the relationship between public and private archives. The author acknowledges that the documents formed in the activities of private organizations have value and are subject to permanent storage for future generations. However, it is impossible to keep all the documentation, therefore, when selecting documents for permanent storage, it is necessary to take into account the principles and criteria for disposal developed by archival science, to apply them in a complex and creatively. When organizing work with private archives and accepting their documents in state archives, it is necessary to proceed from the property of the documents and, depending on the established legal relations and the value of documents of specific organizations, apply different approaches.

Key words: documents, state archives, private archives, territorial archives, principles and criteria for disposal, storage contract, selective reception of documents for storage, archival collection

Stato ed archivi privati: costruzione di un sistema di relazioni e di opportunità di cooperazione

\section{SINTESI}

L'articolo è dedicato alla ricerca di soluzioni ottimali per la costruzione di una relazione tra archivi pubblici e privati. L'autore riconosce che i documenti prodotti nelle attività delle organizzazioni private hanno valore e sono soggetti a conservazione permanente per le generazioni future. Tuttavia, è impossibile conservare tutta la documentazione, pertanto, quando si selezionano i documenti per l'archiviazione permanente, è necessario tenere conto dei principi e dei criteri per lo scarto sviluppati dalla scienza archivistica, per applicarli in modo complesso e creativo. Quando si organizzano lavori con archivi privati e si accettano i loro documenti negli Archivi di Stato, è necessario procedere dalla proprietà dei documenti e, in base ai rapporti giuridici stabiliti e al valore dei documenti di organizzazioni specifiche, applicare approcci diversi.

Parole chiave: documenti, Archivi di Stato, archivi privati, archivi territoriali, principi e criteri per lo scarto, contratto di conservazione, ricezione selettiva di documenti per la conservazione, raccolte archivistiche

\section{Državni in zasebni arhivi: izgradnja sistema relacij in priložnosti sodelovanja}

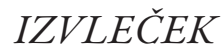

Članek je namenjen iskanju optimalnih rešitev za izgradnjo odnosov med državnimi in zasebnimi arhivi. Avtor priznava, da imajo dokumenti, oblikovani v dejavnostih zasebnih organizacij, vrednost in so predmet trajne hrambe za prihodnje generacije. Ker pa je nemogoče hraniti vso dokumentacijo, je pri izbiranju dokumentov za trajno hrambo treba upoštevati določena načela in merila, ki jih je razvila arhivska znanost in jih uporabimo v kompleksni in ustvarjalni obliki. Pri organizaciji dela z zasebnimi arhivi in sprejemu njihovih dokumentov v državne arhive je potrebno izhajati iz vrednosti dokumentov in, odvisno od uveljavljenih pravnih razmerij ter vrednosti dokumentov posameznih organizacij, uporabiti različne pristope.

Ključne besede: dokumenti, državni arhivi, zasebni arhivi, teritorialni arhivi, principi in kriteriji odbiranja, pogodba o skladiščenju, selektivna recepcija za skladiščenje dokumentov, arhivska zbirka 
Азяржаўныя і прыватныя архівы: пабудова сістэмы ўзаемаадносін і магчымасці супрацоўніцтва

\section{РЭЗЮМЭ}

Артыкул прысвечаны пошуку аптымальных рашэнняў пабудовы ўзаемаадносін паміж дзяржаўнымі і прыватнымі архівамі. Аўтар прызнае, што дакументы, якія ўтварыліся ў Азейнасці недзяржаўных арганізацый, маюць каштоўнасць і падмягаюць пастаяннаму захоўванню Аля будучых пакаленняў. ААнак захаваць усю Аакументацыю немагчыма, таму пры адборы дакументаў дмя пастаяннага захоўвання неабходна ўлічваць распрацаваныя архівазнаўствам прынцыпы і крытәрыі экспертызы каштоўнасці, прымяняць іх у комплексе i творча. Пры арганізацы работы з прыватнымі архівамі і прыёме іх дакументаў у дзяржаўныя архівы неабходна зыходзіць з права ўласнасці на дакументы і, у залежнасці аА склаўшыхся прававых адносін і каштоўнасці дакументаў канкрэтных арганізацый, прымяняць розныя падыходы.

Кмючавыя словы: дакументы, Азяржаўныя архівы, архівы недзяржаўных арганізацый, тэрытарыямьныя архівы, прынцыпы і крытэрыі экспертызы каштоўнасці, дагавор захоўвання, выбарачны прыем дакументаў, архіунная калекцыя

\section{Introduction}

In the activities of various organizations, an enormous number of different documents are formed every year. Initially, any document is created for specific practical purposes - for fixing the fact of making a decision and bringing it to the interested organizations or individuals, fixing certain legal norms, proving business transactions, fulfilling legal obligations, etc.

Archivists perfectly realize that not a single document is initially created in order to be kept in the archive. At the same time, they understand very well that after reaching the purpose for which it was created, the document loses its practical importance (practical value) for its creator or owner in terms of organizing business processes, legal regulation, financial reporting, information exchange. Taking into consideration that storing large amounts of documents is costly, both financially and organizationally, the owners of the documents are mostly interested in getting rid of those documents that have already become "unnecessary" for them as soon as possible.

Completely differently to the documents, that have performed their operative functions, attitude archivists. Their main task is to accept, take into account and preserve documents released from operative circulation, as well as to ensure their use in scientific, historical, social, cultural and other socially significant purposes. However, for archivists, not all the documents are of interest. On the one hand, it is impossible physically to save the entire complex of documents that has been created in various organizations. On the other hand, the potential of their use as historical sources in scientific-historical and other socially significant purposes varies a lot. Therefore, one of the most important and most complicated tasks, that archivists constantly have to solve, is the task of selecting the most valuable documents with the appropriate potential for storage.

To solve this problem archivists developed principles and criteria for examining the value of documents. Through a comprehensive application, they allow to set the disposal dates for documents and select the most valuable of them for permanent storage in archives

One of the important selection criteria is the criterion of "the role and significance of the organization or person, in whose activities the documents were formed, in the system of public administration, in various fields of economic, political and public life" (Правика работы архивов государственных органов и иных организаций, 2012, par. 49). According to this criterion the most valuable documents are to be created in the activities of state bodies and other state enterprises and organizations. However, the documents are formed not only in their activities, but also in the activities of private companies and public associations.

In this regard, archivists need to determine the answers to a number of questions. Can these documents have scientific, historical, political, socio-cultural or other social significance? Should the most valuable of them be kept permanently in the archives? Should they be transferred for permanent storage to state archives? If so, how should the relationship between state and private archives be built? 


\section{State and non-state parts of the national archival fond}

Most archivists in different countries agree that documents of private organizations can have a scientific, historical and other lasting value and on this basis they are subject to permanent storage in the archives.

According to the Law On Archival Work and Records Management in the Republic of Belarus, the National Archive Fond (hereinafter - NAF) of the country consists of two parts - state and non-state (Закон Республики Беларусь Об архивном деле и делопроизводстве в Республике Беларусь, 2011, art. 9).

The state part of NAF consists of documents of:

the President, the Parliament, the Government, the Constitutional and Supreme Courts, other state bodies of the central and local levels and subordinate bodies and organizations located on the territory of the Republic of Belarus;

state organizations, military formations that were or are located outside the Republic of Belarus;

organizations, the share of state property in the statutory fund of which is more than 50 percent;

republican state-public associations, political parties and other public associations, their unions (associations) formed before the introduction of their registration in accordance with the established procedure and stored in state archives;

religious organizations formed before the separation of church and state; of Belarus;

other organizations that existed on the territory constituting the modern territory of the Republic

organizations and citizens whose documents have entered into the ownership of the state, including those from abroad.

The non-state part of the NAF is formed from documents in the ownership of:

republican state-public associations, political parties and other public associations, their unions (associations) formed after the introduction of their registration in accordance with the established procedure;

religious organizations formed after the separation of church and state;

other non-state organizations.

The non-state part of the NAF also includes documents that were formed during the life of citizens (their families, families) or acquired by them legally and owned by them.

The very concept of NAF in the Law is defined as a historically formed and constantly replenishing collection of documents that have historical, scientific, social, economic, political or cultural value, reflecting the material and spiritual life of the Belarusian people (Закон Республики Беларусв Об архивном деле и делопроизводстве в Республике Беларусь, 2011, art. 2).

Thus, the Belarusian Archival Law recognizes that valuable documents that should be permanently stored in archives can be formed in the activities of private organizations. For the storage of such documents, the Law requires all state bodies, state and private organizations to create archives. Their leaders are obliged to create conditions for the reception, storage, stocktaking and use of the documents ( 3 aкон Республики Беларусь Об архивном деле и делопроизводстве в Республике Беларусв, 2011, art. 12).

\section{The right of ownership to documents. Approaches to construction of rela- tionships between state and private archives}

If the selection and transfer to state archives of valuable documents formed in the activities of state bodies and other state organizations does not cause legal obstacles, then the selection, transfer and storage of valuable documents of the most significant private organizations has its difficulties. 
When solving this problem, it is necessary to take into account such a factor as the ownership of these documents. Documents created in the activities of state organizations are the property of the state. Documents of private organizations are the property of their founders. Therefore, in order to transfer the documents from private archives for permanent storage to state archives, it is necessary to resolve the issue of transferring ownership of these documents and, on this basis, to build a clear system of relations between state and private archives. Note that this point of view is shared not only by Belarusian, but also by foreign archivists (Жукова, 2018, p. 43).

The legislation allows for the replenishment of the state part of the NAF with documents of private organizations: "the state part of the NAF can be supplemented by documents of organizations and citizens that have come into the ownership of the state on the grounds provided for by law". NAF, including its state part, can be replenished through donation, inheritance, purchase of documents and by otherways not inconsistent with the law (ЗаконРеспублики Беларусь Обархивномделеиделопроизводстве в Республике Беларусв, 2011, art. 9). ved.

However, in the practical implementation of these regulations, a number of issues need to be sol-

Since for archivists the most valuable are the documents formed in the activities of the organizations that are most significant in the system of public administration and public life, the archival law establishes that the state part of the NAF is formed from documents of government agencies, other organizations and citizens included in the lists of sources for the acquisition of state archives. Private organizations and citizens are included in these lists with their consent on the basis of a storage contract.

However, the state part of the NAF consists of documents not only of state bodies (central and local), but also bodies and organizations subordinate to them. Such organizations can be either fully state or mixed ownership (for example, joint-stock companies). The law establishes that the state part of the NAF also includes documents of organizations, the share of state property in the statutory fund of which is more than 50 percent (Закон Республики Беларусь Об архивном деле и делопроизводстве в Республике Беларусь, 2011, art. 9).

Despite the fact that the new Archival Law has been in effect for more than 5 years, there has not been a definite single position elaborated in the practice of building relations between state archives and organizations of mixed ownership.

This is largely due to the fact that, according to legal interpretations, organizations of mixed ownership are considered as private organizations, regardless of which percentage of their statutory fund is owned by the state and which is private, and also regardless of whether such organizations are subordinate to state bodies and other state organizations. Despite the fact that in the Republic of Belarus there is a National Classifier of Forms of Ownership that establishes the names of such forms of ownership as "mixed ownership without foreign participation", "mixed ownership with foreign participation", "mixed ownership with foreign participation without a share of state property", "mixed ownership with foreign participation, including the share of state property" (Постановмение Государственного комитета по стандартизации, метрологии и сертификации Республики Беларусь от 30.12.1999 N. 28 «Об утвержАении, введении в действие и изменении государственных стандартов, Правих ЕЭК ООН, классификаторов и руководящих документов») in practice all such organizations are classified as non-state (private).

In this regard, some state archives build relationships with such organizations that are formally non-state, in isolation from the provisions of article 9 of the Archive Law and include them in the lists of sources for the acquisition on the basis of storage contracts with the collection of fees for the storage of documents received from them and for the methodical and consultative assistance providing to them as to the sources for acquisition. The most revealing example is the Open Joint Stock Company "Belaruskalij", which is an organization of state importance with direct subordination to the Government of the Republic of Belarus (100 percent of shares are owned by the state). Despite these circumstances, OJSC "Belaruskalij" is included in the list of sources for the acquisition of the relevant state archive on the basis of a storage contract with the collection of fees for storage of accepted documents and provision of methodological and consulting assistance. 
Another factor that causes the uncertainty of interpretations and the ambiguity in the application of the legislative provisions concerning the construction of the relationship between state archives and organizations of mixed and non-state forms of ownership ${ }^{1}$ is the imperfection of the language of the Archive Law. The law uses the concept of a "contract of storage" in different contexts: as when transferring ownership of documents of a non-state part of the NAF to the state one (and on this basis transferring the documents themselves from private to state archives), and when organizing temporary storage of documents of a non-state part of the NAF in state archives without transferring ownership of documents (the so-called "depository storage") (Закон Республики Беларусь Об архивном деле и делопроизводстве в Республике Беларусь, 2011, art. 14, 18).

It is also important that the fact of transfer of documents from non-state organizations to state ownership in the contracts of storage concluded by state archives with non-state organizations is not reflected in any way. According to the Archive Law, non-state organizations and citizens can transfer their documents to state ownership in accordance with the law. However, this position is lacking in the exemplary forms of storage contracts established by the Department on Archives and Record Management of the Ministry of Justice of the Republic of Belarus, with which state archives are guided in drawing up their specific contracts (Методические документы по архивному деку и делопроизводству. Формы договоров. Примерная форма договора хранения документов государственной части Национального архивного фонАа Республики Беларусь (установлена приказом директора Аепартамента по архивам и делопроизводству Министерства юстиции Республики Беларусь от 28.05.2014 N. 29); Примернал форма договора хранения документов государственной части Начионального архивного фонда Республики Беларусь до истечения установленных сроков их временного хранения (установлена приказом первого заместителя директора департамента по архивам и делопроизводству Министерства юстищии Республики Беларусв от 21.06.2013 N. 29). In this situation, a certain legal vacuum arises.

Currently, BelNIIDAD is developing a methodological tool that would allow solving this problem and offering the state archives a unified optimal methodology for building relationships with organizations whose documents relate to the non-state part of the NAF.

\section{Peculiarities of construction of relationships of state archives and typical private organizations}

Along with significant, as a rule, large and unique private organizations in whose activities documents are created (and which, from the point of view of archivists, are valuable and are the subject to permanent storage), there is a huge number of private firms whose role and significance in the economic, social and political life of the state and society is not so great, and sometimes not at all noticeable. It can be numerous trade, production, construction organizations, organizations in the sphere of rendering public services to the population, etc. The composition of the documentation of such numerous organizations operating in a certain field of activity (for example, in retail) is the same. At the same time, the volume of documentation formed in them is very significant.

Archival legislation does not make exceptions for such private organizations. Their documents refer to the non-state part of the NAF, they must create archives to store documents. Moreover, for a significant set of documents of all non-state organizations, the legislation establishes a permanent terms of storage (Перечень типовых документов Национального архивного фонда Республики Беларусь, образующихся в процессе Аеятельности государственных органов, иных организаций и индивидуальных предпринимателей, с указанием сроков хранения, 2018). And it does not matter whether such a non-state organization is a source of acquisition of the state archive or not. The only difference is that non-state organizations, included in the lists of source for acquisition of state archives, transfer their documents to state archives in accordance with storage contracts within a specified time frame, and all the others keep them independently in their private archives.

Have the documents of such private organizations an imperishable value for the state, society and state archives?

1. The National Classifier of Forms of Ownership 002-99 establishes the names of such forms of non-state property as "private property", "property of individuals", "property of non-state legal entities", "foreign property", "property of foreign states", "property of foreign legal entities and individuals", "property of international organizations", "property of stateless persons". 
At first glance, the norm established by the legislation, which prescribes to all non-state organizations to keep a certain set of documents permanently, allows a positive answer to this question. However, how can we realize in practice the task of preserving them, considering that the physical and financial capabilities of state archives for receiving documents for permanent storage are limited? Moreover, in this case, such an important criterion for disposal of documents, as the role and importance of the organization or person in whose activities the documents were formed, becomes meaningless. The norm obliging non-state organizations that are not sources for the acquisition of state archives, to keep documents permanently in their own archives, causes a lot of questions, since this requires considerable financial, organizational and labor costs, which significantly worsens the business conditions.

In our opinion, it should be recognized that mass uniform documents of similar non-state organizations that are not sources for acquisition of state archives are indeed of lasting value, but not all of them despite the norms of the current legislation.

Obviously, this contradiction requires resolution. What solution can archivists offer? To answer this question, let us turn to a not very distant history.

According to the Archival Law, the documents of the NAF, which lost the owner or whose owner is unknown or is deprived of the right to own these documents in accordance with the procedure established by the law, are transferred to state ownership (Закон Республики Беларусв Об архивном деле и делопроизводстве в Республике Беларусь, 2011, art. 16). Documents may lose the owner for various reasons, but the main one is the liquidation of organizations. In the event of the liquidation of organizations that are not sources for acquisition of the state archives, their documents, including those on personnel, are transferred to the territorial (city or district) archives of local executive and administrative bodies or to the archives of the parent organization (archives of the founder) (Закон Республики Беларусь Об архивном деле и делопроизводстве в Республике Беларусь, 2011, art. 19).

Territorial (city and district) archives of local executive and administrative bodies are not state archives (Закон Республики Беларусь Об архивном деле и делопроизводстве в Республике Беларусь, 2011, art. 13). The beginning of their creation was laid in 1998 by a decree of the Government to ensure the preservation of documents on the personnel of liquidated non-state economic entities that do not have legal successors and are not sources for acquisition of state archives. The first original title of these archives also corresponded to the declared purpose: "district, city archives by personnel documentation" (Постановление Совета Министров Республики Бемарусь от 26 марта 1998 г. N. 464 «Об основных направлениях развития архивного дела и делопроизводства в Республике Беларусь до 2000 года», 1998, par. 4).

However, over time, issues related to the need to preserve not only personnel but the other documentation with unexpired storage periods formed in the activity of liquidated organizations began to arise. First of all, the state was concerned with the need to preserve documents of a fiscal and property nature. This was reflected in the Decree of the President of the Republic of Belarus of March 16, 1999, No. 11, where for the first time the concept of "territorial (city or district) archives of the local executive and administrative bodies" was used instead of the concept of "district and city archives on personnel documentation” (Аекрет Президента Республики Беларусь от 16 марта 1999 г. N. 11 «Об упорядочении государственной регистрации и миквидации (прекращения деятельности) субъектов хозяйствования», 1999).

On the other hand, at the turn of the 20th - 21st centuries the archival service of Belarus has not yet decided on the prospects for building a system of relations with non-state organizations, whose documents constitute the non-state part of the NAF, although in the first archival law adopted in 1994 this part was already singled out (Закон Республики Бемарусь О Национальном архивном фонде и архивах в Республике Бемарусь, 1994).

Fears for the quality and completeness of the acquisition of state archives by documents in the conditions of the reduction of the public sector, the emergence of organizations of new (private) forms of ownership, the understanding of the importance of preserving for future generations valuable documents formed in the activities of private and other non-state organizations, led to the fact that in 2001 the first national list of typical documents with the indication of the terms of their storage included the norm, according to which all non-state organizations in determining the storage terms for the documen- 
ts formed in their activities were required to store a certain set of documents permanently - as well as state bodies and other state organizations who were the sources for acquisition of state archives (Постановление Государственного комитета по архивам и делопроизводству Республики Беларусь от 6 августа 2001 г. N. 38 «ОбутвержАении Перечня типовых документов органов государственной власти и управления, учреждений, организаций и преАприятий Республики Беларусь по организации системы управления, ценообразованию, финансам, страхованию, управлению государственным имуществом, приватизации, внешнеэкономическим связям с указанием сроков хранения и Положения о порядке его применения », 2001). That is, virtually all non-state organizations were identified as sources (or potential sources) for acquisition of state archives. The facts of concluding contracts with the state archives and including them in the appropriate lists of sources of state archives was not taken into account.

A similar norm was duplicated in the list of typical documents with the indication of the terms of their storage approved in 2006 (Постановление Министерства юстиции Республики Беларусь от 14 Аекабря 2006 г. N. 82 «Об утверждении Перечня типовых документов органов государственной власти и управления, организаций Республики Беларусь по оперативному и статистическому учету и отчетности, электронным информационным ресурсам, трудовым отношениям, социальной защите, работе с каАрами, образованию, таможенному контролю, материально-техническому обеспечению, административно-хозяйственной деятельности, делопроизводству, работе архивов организаций с указанием сроков хранения», 2006) and acting in parallel with the first one, and then rigidly fixed in the combined list of typical documents with the indication of the terms of their storage adopted in 2012 instead of the first two lists (Постановление Министерства юстиции Республики Беларусь от 24 мая 2012 г. N. 140 «О некоторьх мерах по реализачии Закона Республики Беларусь om 25 ноября 2011 года “Об архивном деле и делопроизводстве в Республике Беларусь"», 2012). At the same time, the presence or absence of a share of state property in the statutory fund of such non-state organizations and its size does not matter.

This approach led to the fact that at present in all non-state organizations (including organizations of mixed ownership) the certain set of documents should be kept permanently.

At first this circumstance did not cause serious problems due to the small amount of accumulated documents of permanent storage. But over time, with the accumulation of documents of permanent storage in non-state organizations, which have been operating for a long period of time and are not sources for acquisition of state archives, the situation began to escalate. Difficulties are also experienced by territorial archives, which are overloaded with documents. Because of this, they physically cannot store a complete set of documents of liquidated organizations with unexpired storage periods, and limit it only by documents of permanent storage and personnel, although they must take for storage all these documents. Moreover, some territorial archives are not able to receive in full complex even the documents of permanent storage.

Obviously, by the present time the issue of abolishing the norm obliging all non-state organizations to keep the certain set of documents in their archives permanently is fully ready for the solution. Its temporary nature was evident initially (Rybakov, 2003).

But in this case, how can the most valuable documents of non-state organizations be preserved for future generations? It seems that the quality of NAF replenishment with documents from the archives of non-state organizations will not be affected. On the one hand, the Archive Law allows to include non-state organizations in the lists of sources for acquisition of state archives on the basis of the contract of storage and to receive documents valuable for "citizens, society and state" in the state ownership. On the other hand, documents of non-state organizations that have not concluded a storage contract with the state archive will continue to be deposited in territorial archives - not for permanent storage, but for temporary storage after the liquidation of these organizations. The documents received in this way in the territorial archives, recognized as valuable and already owned by the state, can then be transferred for permanent storage to state archives, but not in full complex, but selectively, and by forming collections of the most interesting documents of various organizations.

This type of archival work is rather complicated, requiring proper methodological support, and the archival science have to work over it in the near future. 


\section{Conclusion}

The construction of a system of interaction between state and private archives is an important task in the preservation of documentary heritage. The documents of non-state organizations should be recognized as potentially valuable, and archivists should take care of them and to be sure they reach the future generations. At the same time, it is obvious that all the documents that are even recognized as valuable cannot be preserved in full complex because of financial and physical constraints. So archivists need to solve the tasks of selecting the most valuable of them and develop mechanisms to implement this process in practice. At the decision of these problems first of all it is necessary to consider the property right to documents, and also special features of the national legislation.

\section{References}

Правила работы архивов государственных органов и иных организаций. (2012). Национальный реестр правовых актов Республики Беларусь, N. 8.

Закон Республики Беларусь Об архивном деле и делопроизводстве в Республике Беларусь. (2011). Национальный реестр правовых актов Республики Бемарусь, N. 136.

Жукова М.П. (2018). Современная нормативная и методическая база отбора документов на архивное хранение. In: Отечественные архивы. N. 1, pp. 40-47.

Постановление Государственного комитета по стандартизации, метрологии и сертификации Республики Беларусь от 30.12 .1999 N. 28 «Об утверждении, введении в действие и изменении государственных стандартов, Правил ЕЭК ООН, классификаторов и руководящих документов». (1999). Available at http:// naviny.org/1999/12/30/by60449.htm (accessed on 08.06.2018).

Методические документы по архивному делу и делопроизводству. Формь договоров. Примерная форма договора хранения документов государственной части Национального архивного фонда Республики Беларусь (установлена приказом директора Аепартамента по архивам и делопроизводству Министерства юстищии Республики Беларусь от 28.05.2014 N. 29); Примерная форма договора хранения документов государственной части Начионального архивного фонда Республики Беларусь до истечения установленных сроков их временного хранения (установлена приказом первого заместителя директора Аепартамента по архивам и делопроизводству Министерства юстиции Республики Беларусь от 21.06.2013 N. 29). (2013). Electronic resource. Available at http://archives.gov.by/index.php?id=133837\#fd (accessed on 08.06.2018).

Перечень типовьх документов Нащионального архивного фонда Республики Беларусь, образующихся в процессе деятельности государственныцх органов, иныхх организачий и индивидуальныцх предпринимателей, суказанием сроков хранения (2018). Минск: БеАНИИААА.

Постановление Совета Министров Республики Беларусь от 26 марта 1998 г. N. 464 «Об основныцх направлениях развития архивного дела и делопроизводства в Республике Беларусь до 2000 года». (1998). Available at http://naviny.org/1998/03/26/by65731.htm (accessed on 08.06.2018).

Аекрет Президента Республики Беларусь от 16 марта 1999 г. N. 11 «Об упорядочении государственной регистращии иликвидации (прекращения деятельности) субъектов хозяйствования». (1999). Национальный реестр правовых актов Республики Бемарусь, ‥ 17.

Закон Республики Беларусь О Начиональном архивном фонде и архивах в Республике Беларусв. (1994). Ведамасці Вярхоуннага Савета Рэспубкікі Бемарусь, 1995 г., N. 17.

Постановление Государственного комитета по архивам и делопроизводству Республики Беларусв от 6 августа 2001 г. N. 38 «Об утверждении Перечня типовых документов органов государственной власти и управления, учреждений, организащий и предприятий Республики Беларусь по организащии системь управления, ценообразованию, финансам, страхованию, управлению государственным имуществом, приватизаиии, внешнеэкономическим связям с указанием сроков хранения и Положения о порядке его применения». (2001). Национальный реестр правовых актов Республики Беларусь, 2001 г., N. 86.

Постановление Министерства юстищии Республики Беларусь от 14 декабря 2006 г. N. 82 «Обутверждении Перечня типовых документов органов государственной власти и управления, организачий Республики Беларусь по оперативному и статистическому учету и отчетности, электронным информационным ресурсам, трудовьм отношениям, соииальной защите, работе с кадрами, образованию, таможенному контролю, материально-техническому обеспечению, административно-хозяйственной деятельности, делопроизводству, работе архивов организаций с указанием сроков хранения». (2006). Национальный реестр правовых актов Республики Бемарусь, 2007 г., N. 30. 
Andrei RYBAKOU: State and Private Archives: Construction of the System of Relations and Opportunities of Cooperation, 229-237

Постановление Министерства юстищии Республики Беларусь от 24 мал 2012 г. N. 140 «O некоторых мерах по реализачии Закона Республики Беларусь от 25 ноября 2011 года "Об архивном деле и делопроизводстве в Республике Беларусь”». (2012). Национальный реестр правовых актов Республики Бемарусь, 2012 г., ‥ 8.

Rybakov, A. (2003). Legal Regulation of Records Management and Involvement of the Belarusian Archives in this Process. In: Archives in the society: ICA pre-congress meeting - Vienna 2004: papers of the International Conference Elblag May 22-24, 2003, pp. 254-258. Warszawa: Naczelna Dyrekcja Archiwów Państwowych.

\section{SUMMARY}

The documents formed in the activities of private organizations have value and are the subject to permanent storage for future generations. However, it is impossible to keep all the documentation created in the activities of both state and private organizations. Therefore, when selecting documents for permanent storage, it is necessary to take into account the principles and criteria for disposal developed by archival science, to apply them in a complex and creatively. One of the important selection criteria is the criterion of "the role and significance of the organization or person, in whose activities the documents were formed, in the system of public administration, in various fields of economic, political and public life". When organizing work with private archives and accepting their documents in state archives, it is necessary to proceed from the property of the documents and, depending on the established legal relations and the value of documents of specific organizations, apply different approaches. With the most significant non-state organizations, in whose activities the most valuable documents are formed, it is expedient for state archives to conclude the storage contracts. The contract should provide transfer of documents and ownership of documents from private organizations to the state (state archives) free of charge. On this basis, non-state organizations can be included in the list of sources for the acquisition of state archives. With others, less significant private organizations, whose documents from the archivists' point of view are not so valuable, contracts of storage can be concluded without transfer of ownership of documents, but with reimbursement to the state (state archives) of expenses for temporary storage of their documents. The most valuable documents of such organizations can come in the state archives for permanent storage after the liquidation of these organizations through selective selection and the formation of archival collections. The permanent storage of a certain set of documents of non-state organizations in these conditions is superfluous.

Typology: 1.01 Original scientific article

Submission date: 11.06.2018

Acceptance date: 08.08.2018 